\title{
Non-Linearity Effect of Energy Consumption on Economic Growth: Panel ASEAN-4 Countries
}

Jerome Kueh, Josephine Yau, Audrey Liwan, Yong Sze Wei

To Link this Article: http://dx.doi.org/10.6007/IJARBSS/v10-i8/7642

DOI:10.6007/IJARBSS/v10-i8/7642

Received: 08 May 2020, Revised: 04 June 2020, Accepted: 20 July 2020

Published Online: 16 August 2020

In-Text Citation: (Kueh, Yau, Liwan, \& Wei, 2020)

To Cite this Article: Kueh, J., Yau, J., Liwan, A., \& Wei, Y. S. (2020). Non-Linearity Effect of Energy Consumption on Economic Growth: Panel ASEAN-4 Countries. International Journal of Academic Research in Business and Social Sciences. 10(8), 862-871.

\section{Copyright: (C) 2020 The Author(s)}

Published by Human Resource Management Academic Research Society (www.hrmars.com)

This article is published under the Creative Commons Attribution (CC BY 4.0) license. Anyone may reproduce, distribute, translate and create derivative works of this article (for both commercial and non-commercial purposes), subject to full attribution to the original publication and authors. The full terms of this license may be seen at: http://creativecommons.org/licences/by/4.0/legalcode

Vol. 10, No. 8, 2020, Pg. 862 - 871

Full Terms \& Conditions of access and use can be found at http://hrmars.com/index.php/pages/detail/publication-ethics 


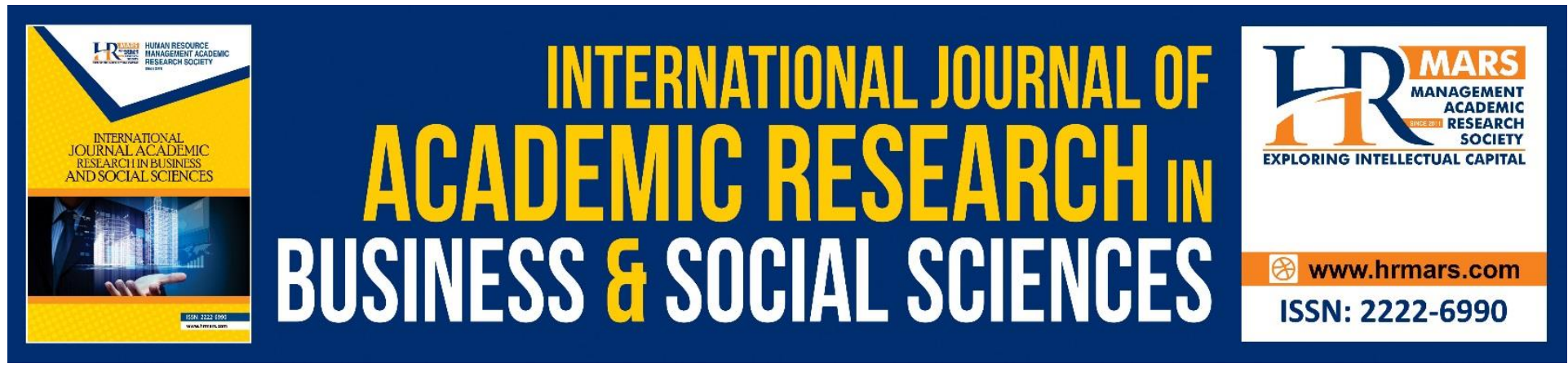

\title{
Non-Linearity Effect of Energy Consumption on Economic Growth: Panel ASEAN-4 Countries
}

\author{
Jerome Kueh, Josephine Yau, Audrey Liwan \\ Faculty of Economic and Business, Universiti Malaysia Sarawak, 94300 Kota Samarahan, \\ Sarawak, Malaysia \\ Yong Sze Wei \\ Faculty of Business and Management, Universiti Teknologi MARA, 94300 Kota Samarahan, \\ Sarawak, Malaysia \\ Email: kshjerome@unimas.my
}

\begin{abstract}
The aim of the study is to investigate the impact of energy consumption on economic growth in ASEAN-4 countries as a whole. In addition, the effect of the non-linearity of the relationship between energy consumption and growth is examined using Threshold Analysis method for the period of 1980 to 2014. Empirical findings indicate that energy consumption has significant positive impact on economic growth in ASEAN-4 countries in the long-run. Furthermore, the non-linearity results show that the impact of the energy consumption on growth become greater when the energy consumption is above the threshold level. This implies that more usage of energy may contribute to the economic growth.
\end{abstract}

Keywords: Energy Consumption, ASEAN-4, Non-Linearity.

\section{Introduction}

Energy demand remain as critical issue in the developed and developing countries, especially in Association of Southeast Asian (ASEAN) region due to the need of energy for development purpose. According to World Energy Outlook 2017 report, the energy demand for ASEAN countries indicating growth of $70 \%$ since 2000 and accounted for $5 \%$ of total global energy demand. 


\section{Figure 1: Energy Consumption of ASEAN-4 Countries from 1980 - 2014}

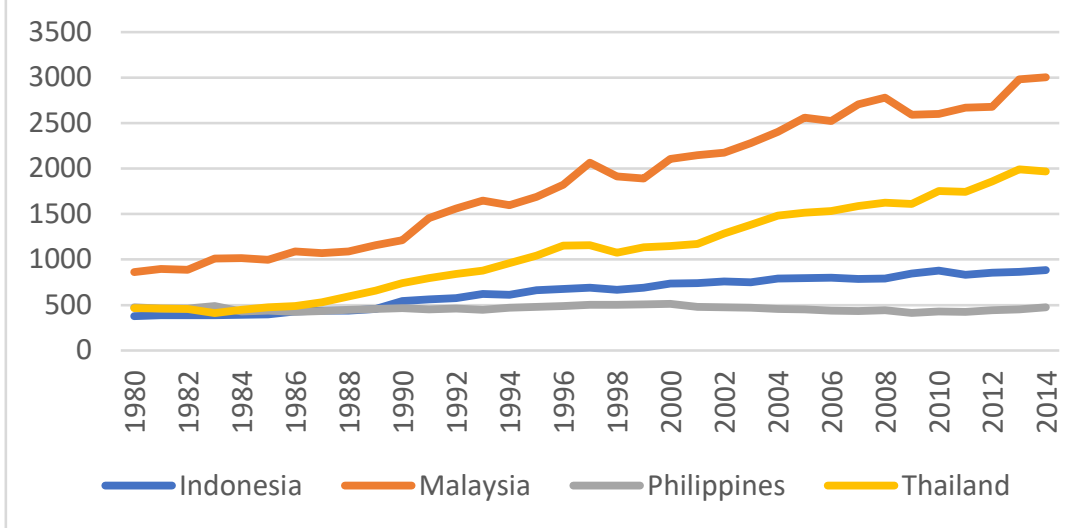

Source: World Development Indicator, World Bank

Figure 1 depicts the level of energy consumption of ASEAN-4 countries namely Indonesia, Malaysia, Philippines and Thailand from 1980 to 2014. Overall, there is an increasing trend of energy consumption for Malaysia and Thailand. In 1980, the level of energy consumption of Malaysia and Thailand stood at approximately $862 \mathrm{~kg}$ of oil and 460 $\mathrm{kg}$ of oil, respectively. Prior to the 1997 Asian Financial crisis, the energy consumption in Malaysia recorded approximately 2,065 kg of oil in 1997 and declined to approximately 1,892 $\mathrm{kg}$ of oil in 1999. Meanwhile, Thailand recorded slight decrease from approximately $1,159 \mathrm{~kg}$ of oil in 1997 to approximately $1,074 \mathrm{~kg}$ of oil in 1998. Although there was a reduction in the energy consumption aftermath 1997 Asian Financial crisis, the energy consumption in both countries exhibit any increasing trend and reached approximately 3,003 $\mathrm{kg}$ of oil and approximately $1,969 \mathrm{~kg}$ of oil, respectively, in 2014 . In contrast, the energy consumption level is relatively lower in Indonesia and Philippines. The energy consumption trend in Indonesia is showing increasing trend from approximately $378 \mathrm{~kg}$ of oil in 1980 to approximately $884 \mathrm{~kg}$ of oil in 2014. Nevertheless, the energy consumption trend in Philippines exhibits minor changes with approximately $473 \mathrm{~kg}$ of oil in 1980 to approximately $474 \mathrm{~kg}$ of oil in 2014.

Although, energy is highly demanded for development purpose, however, high level of energy consumption in the long-run may be detrimental to the economic growth of ASEAN4 countries. This can be seen from the environmental point of view where energy usage may lead to pollution such as carbon emission. Although most of the literature support the positive association between energy consumption and economic growth, but limited concern on the possibility of the different impact of energy on growth based on threshold effect. Therefore, viewing the dynamic development in the energy sector in ASEAN region, it is essential to understand the effect of the energy consumption towards economic growth of ASEAN-4 countries by taking into account the threshold effect. The objective of the study is:

- to investigate the impact of the energy consumption towards economic growth of ASEAN4 countries as a whole.

- to identify the turning point of the energy consumption and heterogeneous effects either above or below the threshold level on economic growth of ASEAN-4 countries.

\section{Literature Review}

There are a wide range of literatures discussing about the role of the energy demand on economic growth. Most of the studies support the positive energy-growth association (such 
as Rahman et al., 2015; Kasperowicz, 2014; Yildrim et al., 2014; Adhikari and Chen, 2012; Narayan and Smyth, 2008; Lee, 2005; Soytas and Sari, 2003; Imran and Siddiqui, 2010; Masih and Masih, 1996). The following section provide several discussions about the literatures of the relationship between energy consumption and economic growth.

Among a few studies supporting energy-led-growth hypothesis are as followed. Narayan and Smyth (2008) examined the association between capital formation, energy consumption, and real GDP for sample of G7 countries (Canada, France, Germany, Italy, Japan, United Kingdom and United States). Their empirical findings showed that the causality was running from capital formation and energy consumption have positive impact on growth in the long-run. Kasperowicz conducted study on 12 European countries from 2000 to 2012 and empirical outcome support energy leg growth relationship. Meanwhile, Rahman et al. (2015) investigated the causal linkage between energy consumption and economic productivity of Malaysia where their study includes disaggregate levels of energy on growth. They discovered that type of energy that have negative impact on growth are coal and electricity consumption due to inefficiency. Yildrim et al. (2014) reexamined the association between energy consumption and growth of Indonesia, Malaysia, Philippines, Singapore and Thailand via panel data causality. Their empirical results indicated that energy-growth only valid for Indonesia, Malaysia and Philippines.

Adhikari and Chen (2012) examined the long-run relationship between energy consumption and economic growth for 80 developing countries from 1990 to 2009 where sample countries was classified into three income groups: upper middle income countries, lower middle income countries and low income countries. Empirical results showed that significant positive association between energy consumption and economic growth for upper middle income countries and lower middle income countries. Imran and Siddiqui (2010) studied the relationship between energy consumption and economic growth for the panel of three SAARC countries using panel error correction model. Their causality results support the positive relationship between energy consumption and growth. Lee (2005) examined comovement and the causality of energy-growth relationship for 18 developing countries from 1975 to 2001. The results showed evidence of long-run and short-run causalities from energy consumption to GDP only for the sample countries. Soytas and Sari (2003) investigated energy-growth for G7 countries and emerging markets. Their results revealed positive relationship between energy consumption and economic growth can be observed in only in France, Japan, Germany and Turkey.

It can be seen that most of the literatures support the energy-led-growth relationship. However, as far as concern, none are examining the possibility of different impact of energy on growth when considering the threshold effect of energy level.

\section{Methodology}

The data used in this study were obtained from World Development Indicator (WDI) from 1980 to 2014. These aggregate data of ASEAN-4 countries comprise of gross domestic product per capita as dependent variable, energy usage ( $\mathrm{kg}$ of oil equivalent per capita) as the main independent variable, total trade and domestic private credit as control variables. All the data were transformed into logarithm in order to standardized the measurement units. 
The empirical model for this study can be formed as below:

$$
L G D P_{t}=\beta_{0}+\beta_{1} L E U_{t}+\beta_{2} L T_{t}+\beta_{3} L D C_{t}+\varepsilon_{t}
$$

where $L G D P$ is logarithm of Gross Domestic Product, $L E U$ is logarithm of energy usage, $L T$ is logarithm of trade, $L D C$ is logarithm of domestic credit and $\varepsilon$ refers to disturbance. $\beta_{0}$ is the intercept while $\beta_{1}, \beta_{2}$, and $\beta_{3}$ are the coefficients of the parameters of estimate.

Augmented Dickey-Fuller (ADF) (1979), Philip Perron (PP) and Kwiatkowski-PhillipsSchmidt-Shin (KPSS) are utilized to test the stationarity of the time series variables.

Augmented Dickey-Fuller (ADF) Unit Root Test Augmented Dickey-Fuller (ADF) (1979) unit root test is employed to test the time series properties to evade spurious regression. Equation (2) indicates the equation for the ADF test.

$$
\Delta Y_{t}=\beta_{0}+\beta_{1} t+\theta_{1} Y_{t-1}+\sum \theta_{2 j} \Delta Y_{t-j}+\varepsilon_{t}
$$

where $Y_{t}$ is variable of interest, $\Delta$ is to differencing operator, $t$ is to time trend and $\varepsilon$ is to the error term. The parameters to be estimated are $\beta_{0}, \beta_{1}, \theta_{1}$ and $\theta_{2 j}$ where the null and alternative hypotheses are as followed:

$$
\begin{aligned}
& H_{0}: \theta_{1} \geq 0 \\
& H_{a}: \theta_{1}<0
\end{aligned}
$$

when the value of computed test statistic is larger than the critical value, the null hypothesis of $Y_{t}$ has a unit root or non-stationary can be rejected and vice versa.

Phillips-Perron (PP) Unit Root Test

Phillips and Perron (PP) (1988) unit root test also incorporated in this study to deal with serial correlation and heteroscedasticity in the errors. PP has test regression as follow:

$$
\Delta y_{t}=\beta^{\prime} D_{t}+\pi y_{t-1}+\mu_{t}
$$

where $\mu_{t}$ is $I(0)$ and may be heteroscedasticity. The PP tests will modify the test statistic $t_{n}=$ 0 and $T_{\pi^{\wedge}}$ to correct the serial correlation and heteroscedasticity in the errors $\mu_{t}$.

\section{Kwiatkowski Phillips Schmidt Shin (KPSS) Unit Root Test}

KPSS is different from others unit root test which the null hypothesis of this test is opposite with others unit root test such as ADF test and PP test. KPSS test is based on residuals from OLS regression, the LM statistic is defined as follow:

$$
L M=\sum_{t} \frac{S(t)^{2}}{\left(T^{2} f_{0}\right)}
$$

where $f_{0}$ is an estimator of the residual spectrum at frequency zero and where $S(t)$ is a cumulative residual function.

\section{Johansen and Juselius Cointegration Test (JJ Test)}

The purpose of this test is to test the existence of long-run equilibrium in the model. There are two measurements, which are trace test and maximum eigenvalue tests. The equation for trace test is expressed as below:

$$
\lambda_{\text {trace }}=-T \sum_{i=r+1}^{n} \ln \left(1-\hat{\hat{\lambda}}_{i}\right)
$$


where $T$ represents the number of valid observations, $\hat{\lambda}_{i}$ is the $i^{\text {th }}$ largest estimated eigenvalue. The null hypothesis for likelihood ratio trace test is the $r<0$ whereas the alternative hypothesis is $r \leq 1, r \leq 2, \ldots r \leq p$.

The equation for maximum eigenvalue test is expressed as below:

$$
\lambda_{\max }=-T \ln \left(1-\hat{\lambda}_{r-1}\right)
$$

where $T$ represents the number of valid observations, $\hat{\lambda}_{i}$ is the $i^{\text {th }}$ largest estimated at $(r-1)$. The null hypothesis of this maximum eigenvalue test is equal to $r$ cointegrating vector and $r+1$ is the alternative hypothesis.

\section{Threshold Regression}

The threshold regression analysis is adopted to identify the threshold level and estimate the effect of the energy consumption on growth as either above or below the threshold level. Equation (7) and (8) depict the setup of the threshold regression.

$$
\begin{array}{lll}
L G D P_{t}=\beta_{1}+\beta_{11} L E U_{t}+\beta_{12} L T_{t}+\beta_{13} L D C_{t}+\varepsilon_{1 t} & \text { if } & L E U_{t} \leq \theta \\
L G D P_{t}=\beta_{2}+\beta_{21} L E U_{t}+\beta_{22} L T_{t}+\beta_{23} L D C_{t}+\varepsilon_{2 t} & \text { if } & L E U_{t}>\theta
\end{array}
$$

where $\theta$ is the threshold level. The threshold values are identified via minimization of the sum of squared errors across the estimated models (Bai and Perron, 2003).

\section{Empirical Findings}

Table 2 shows the results of unit root tests based on ADF, PP and KPSS to test the stationarity of the variables. Under the ADF and PP unit root tests, all the variables are non-stationary at level due to non-rejection of the null hypothesis of contain unit root. However, the variables are stationary after first difference. In term of KPSS results, null hypothesis of contain no unit root is rejected and this implies non-stationary at level, but become stationary after first difference. In summary, the time series variables in the model are $I(0)$ at level and $I(1)$ at first

\begin{tabular}{|c|c|c|c|c|c|c|}
\hline \multirow[b]{2}{*}{ Variables } & \multicolumn{2}{|c|}{$\begin{array}{l}\text { Augmented Dickey-Fuller } \\
\text { (ADF) }\end{array}$} & \multicolumn{2}{|c|}{$\begin{array}{l}\text { Philips Perron } \\
\text { (PP) }\end{array}$} & \multicolumn{2}{|c|}{$\begin{array}{l}\text { Kwiatkowski-Phillips- } \\
\text { Schmidt-Shin } \\
\text { (KPSS) }\end{array}$} \\
\hline & At Level & $\begin{array}{c}\text { First } \\
\text { Difference }\end{array}$ & At Level & $\begin{array}{c}\text { First } \\
\text { Difference }\end{array}$ & At Level & $\begin{array}{c}\text { First } \\
\text { Difference }\end{array}$ \\
\hline$L G D P$ & $-2.2262(1)$ & $-4.1574(0) * * *$ & $-1.9218(2)$ & $-4.1845(1)^{* * *}$ & $0.1086(4)^{* *}$ & $0.0815(1)$ \\
\hline$L E U$ & $-1.1535(0)$ & $-5.0727(0)^{* * *}$ & $-1.3781(3)$ & $-5.0523(2)^{* * *}$ & $0.1596(4)^{* *}$ & $0.1607(2)$ \\
\hline$L T$ & $-0.4393(0)$ & $-4.7623(0)^{* * *}$ & $-0.6406(2)$ & $-4.7570(2)^{* * *}$ & $0.1762(4)^{* *}$ & $0.2512(3)$ \\
\hline$\angle D C$ & $-2.0155(1)$ & $-3.9123(0)^{* * *}$ & $-2.0124(3)$ & $-3.8368(2)^{* * *}$ & $0.1625(4)^{* *}$ & $0.2255(3)$ \\
\hline
\end{tabular}
difference.

Table 2: Unit Root Test Results

Notes: Asterisks *,** and $* * *$ denote significance levels: $10 \%, 5 \%$ and $1 \%$. LGDP $=$ logarithm of GDP per capita, LEU = logarithm of Energy Usage, LT = logarithm of total trade and LDC = logarithm of domestic private credit. Automatic lag selection by Schwarz Info Criterion (SIC) for ADF. Values in parenthesis under ADF refers to lag and under PP and KPSS refers to bandwidth. Null hypothesis under ADF test and PP test state that time series variable is nonstationary, while null hypothesis under KPSS test states that time series variables is stationary. 
The same integration order of the time series variables under the unit root tests enable testing of long-run equilibrium using Johansen and Juselius (1990) cointegration test. Based on the cointegration test results in Table 3, empirical results show that null hypothesis of no-cointegrating vector can be rejected. This indicates presence of one cointegrating vector in the system. Therefore, this implies existence long-run equilibrium relationship between the variables.

Notes: Trace refers to Likelihood Ratio Trace Test while Max refers to Maximum Eigenvalue Test. $k$ denotes as the optimal number of lag and $r$ denotes as the number of cointegration vector(s). The lag length chooses according to the Schwartz criterion (SC). Asterisks **

Table 3: Result of Johansen Cointegration Test

$k=2, r=1$

\begin{tabular}{cccccc}
\hline & Hypothesis & \multicolumn{2}{c}{ Test statistic } & \multicolumn{2}{c}{ Critical values (95\%) } \\
\hline $\mathbf{H}_{\mathbf{0}}$ & $\mathbf{H}_{\mathbf{1}}$ & Trace & Max & Trace & Max \\
\hline$r=0$ & $r=1$ & $61.36733^{* *}$ & $38.1903^{* *}$ & 47.8561 & 27.5843 \\
\hline$r \leq 1$ & $r=2$ & 23.1769 & 19.2137 & 29.7970 & 21.1316 \\
\hline$r \leq 2$ & $r=3$ & 3.9631 & 3.9631 & 15.4947 & 14.2646 \\
\hline$r \leq 3$ & $r=4$ & 0.0005 & 0.0005 & 3.8414 & 3.8414 \\
\hline
\end{tabular}

indicate as the rejection of null hypothesis at $5 \%$ significance level.

Next, Table 4 shows the regression results with non-threshold estimation and with threshold estimation as either below or above the threshold level. Under the non-threshold result, energy consumption has a significant positive impact on economic growth in ASEAN-4 countries with coefficient of 1.578. This finding is consistent with previous studies such as Rahman et al. (2015); Kasperowicz (2014); Yildrim et al. (2014); Adhikari and Chen (2012); Narayan and Smyth (2008); Lee (2005); Soytas and Sari (2003); Imran and Siddiqui (2010); and Masih and Masih (1996). Trade has inverse relationship with economic growth but domestic credit is statistically insignificant. In Table 5, threshold test result indicates that null hypothesis of non-threshold is rejected at $5 \%$ significance level. The $F$-statistic value of 16.59 is greater than F-critical value of 16.19. This implies that existence of threshold in the model. The threshold level is 8.20 , where it is approximately $3,640 \mathrm{~kg}$ of oil.

Table 4: Linear Regression Result

\begin{tabular}{ccc}
\hline Variables & Coefficients & t-statistic \\
\hline & $1.5782^{* * *}$ Non-Threshold & \\
LEU & $-0.3917^{* * *}$ & 42.7751 \\
LT & 0.0248 & -7.1926 \\
LDC & $16.5669^{* * *}$ & 0.5332 \\
C & 90.8974 \\
\hline
\end{tabular}

Notes: Asterisks *,$* *$ and $* * *$ denote significance levels: $10 \%, 5 \%$ and $1 \%$. LGDP $=$ logarithm of GDP per capita, LEU = logarithm of energy usage, LT = logarithm of total trade, LDC = logarithm of domestic private credit and $\mathrm{c}=$ constant. 
Table 5: Threshold Test

\begin{tabular}{cccc}
\hline Null Hypothesis & $\begin{array}{c}\text { F- } \\
\text { statistic }\end{array}$ & F-critical value & Threshold Level \\
\hline 0 vs 1 & $16.59^{* *}$ & 16.19 & 8.20 \\
\hline \multicolumn{2}{l}{$\begin{array}{l}\text { Notes: Asterisks } \\
\text { (Econometric Journal, 2003). }\end{array}$}
\end{tabular}

This study further examines the possibility of the non-linearity of the relationship between energy consumption and economic growth of ASEAN-4 as a whole as shown in Table 6. Under the threshold result where energy consumption is below 8.20 level, energy consumption has significant positive impact on growth with coefficient of 0.675 . In addition, trade and domestic credit also depict positive impact on growth with coefficients of 0.428 and 0.454 , respectively. Under the threshold result where energy consumption is above 8.20 level, energy consumption still has positive impact with larger coefficient of 1.525 . Nevertheless, trade and domestic credit have inverse impact of growth. Empirical findings show that the impact of the energy consumption on growth become greater from coefficient of 0.675 when below the threshold level of 8.20 and become 1.525 when above the threshold of 8.20 . This signifies the essential of the energy consumption where the impact of energy consumption on growth become larger when exceeding the 8.20 threshold level or 3,640 $\mathrm{kg}$ of oil.

Table 6: Non-Linear Regression Results

\begin{tabular}{|c|c|c|}
\hline Variables & Coefficients & $t$-statistic \\
\hline \multicolumn{3}{|c|}{ Threshold: $L E U \leq 8.20$} \\
\hline LEU & $0.6745^{* * *}$ & 5.1900 \\
\hline $\mathrm{LT}$ & $0.4277 * * *$ & 3.9839 \\
\hline LDC & $0.4538^{* * *}$ & 5.5636 \\
\hline C & $16.8089 * * *$ & 42.5578 \\
\hline \multicolumn{3}{|c|}{ Threshold: LEU > 8.20} \\
\hline LEU & $1.5245^{* * *}$ & 37.6543 \\
\hline LT & $-0.4988 * * *$ & -9.5431 \\
\hline LDC & $-0.0249 * * *$ & -0.3815 \\
\hline C & $17.9532 * * *$ & 28.5371 \\
\hline
\end{tabular}

Notes: Asterisks *,$* *$ and $* * *$ denote significance levels: $10 \%, 5 \%$ and 1\%. LGDP = logarithm of GDP per capita, LEU = logarithm of energy usage, $L T=$ logarithm of total trade, LDC = logarithm of domestic private credit and $\mathrm{c}=$ constant.

Table 7 shows the diagnostic tests results for the model. The Jarque Bera Normality test result indicates the residuals are normally distributed where the null hypothesis of the residuals is normally distributed cannot be rejected. There is also no serial correlation problem where the null hypothesis no serial correlation cannot be rejected under the Breusch-Godfrey Serial Correlation LM Test. Furthermore, the variances are homoscedastic where the null hypothesis of variances are constant cannot be rejected under the Heteroskedasticity White Test. There is also no misspecification in the model under the Ramsey RESET Test. The results of the CUSUM test and CUSUM ${ }^{2}$ show that the models are stable. 
INTERNATIONAL JOURNAL OF ACADEMIC RESEARCH IN BUSINESS AND SOCIAL SCIENCES Vol. 10, No. 8, 2020, E-ISSN: 2222-6990 @ 2020 HRMARS

Table 7: Diagnostic Tests

\begin{tabular}{lc}
\hline \multicolumn{1}{c}{ Tests } & Coefficients \\
\hline Normality Test Jarque Bera & 1.8347 \\
& {$[0.3995]$} \\
Breusch-Godfrey Serial Correlation LM Test: & 1.8068 \\
& {$[0.1850]$} \\
Heteroskedasticity Test: White & 0.9969 \\
& {$[0.5102]$} \\
Ramsey RESET Test & 0.276981 \\
& {$[0.6031]$} \\
CUSUM test & Stable \\
CUSUM ${ }^{2}$ test & Stable
\end{tabular}

Notes: Values in the bracket refers to probability.

Figure 2: Stability Test
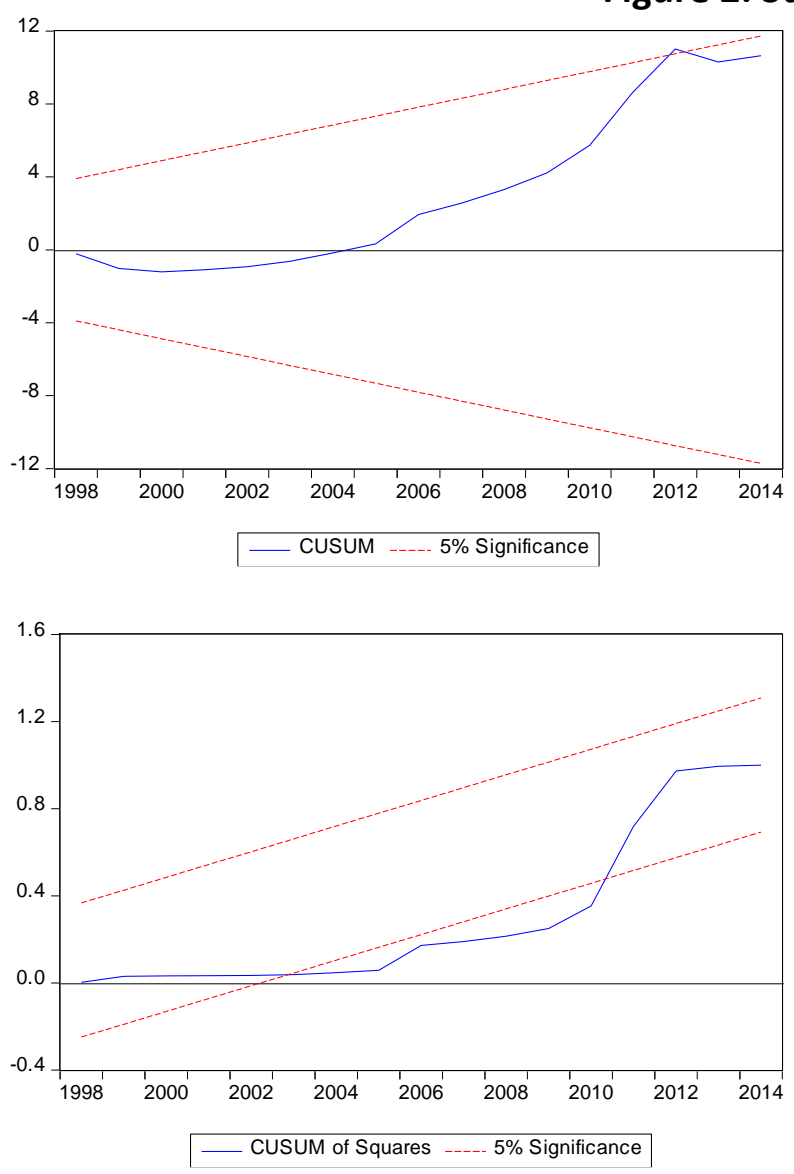
INTERNATIONAL JOURNAL OF ACADEMIC RESEARCH IN BUSINESS AND SOCIAL SCIENCES Vol. 10, No. 8, 2020, E-ISSN: 2222-6990 @ 2020 HRMARS

\section{Conclusion}

This study intends to examine the impact of energy consumption on economic growth in ASEAN-4 countries as a whole. The effect of the non-linearity of the relationship between energy consumption and growth is examined via Threshold Analysis method using annual data from 1980 to 2014. Empirical results show that energy consumption has significant positive impact on economic growth in the panel ASEAN-4 countries. This signifies the importance of the energy usage in stimulating the economic growth in the region. Furthermore, the non-linearity results show that the impact of the energy consumption on growth become greater when the energy consumption is above the threshold level of approximately $3,640 \mathrm{~kg}$ of oil. Initial energy consumption will contribute to growth and when it reaches beyond the threshold level, the impact of the energy consumption on growth become larger. This implies that energy consumption remains key contributor to economic growth in ASEAN4 countries.

This study contributes to the field in term of identifying the threshold level of energy consumption. Despite examining the linearity long-run impact on growth, this study examines the possibilities of non-linearity impact of energy consumption on growth in ASEAN-4 region.

\section{Acknowledgement}

This work was supported by Universiti Malaysia Sarawak [grant numbers F01/SpMYRA/1687/2018].

\section{References}

Adhikari, D., and Chen, Y. (2012), Energy Consumption and Economic Growth: A Panel Cointegration Analysis for Developing Countries, Review of Economic and Finance, 3, 68-80.

Imran, K., and Siddiqui, M. M. (2010). Energy Consumption and Economic Growth: A Case Study of Three SAARC Countries, European Journal of Social Sciences, 16,2, 206-213.

Kasperowicz, R. (2014). Economic Growth and Energy Consumption in 12 European Countries: A Panel Data Approach, Journal of International Studies, 7, 3, 112-122.

Lee, C. (2005) Energy consumption and GDP in developing countries: A Cointegrated Panel Analysis, Energy Economics, 27(3), 415-427.

Narayan, P. K., \& Smyth, R. (2008). Energy Consumption and Real GDP in G7 Countries: New Evidence from Panel Cointegration with Structural Breaks. Energy Economics, 30(5), 2331-2341.

Rahman, M. S., Junsheng, H., Shahari, F., Aslam, M., Masud, M. M., Banna, H., and Liya, M. (2015). Long-Run Relationship Between Sectoral Productivity and Energy Consumption in Malaysia: An Aggregated and Disaggregated Viewpoint, Energy, 86, 436-445.

Soytas, U., and Sari, R. (2003). Energy Consumption and GDP: Causality Relationship in G-7 Countries and Emerging Markets, Energy Economics, 25, 33-37.

World Energy Outlook Report. (2017), International Energy Agency. World Development Indicator, World Bank.

Yildrim, E., Aslan, A., Ozturk, I. (2014). Energy Consumption and GDP in ASEAN Countries: BootstrapCorrected Panel and Time Series Causality Tests, The Singapore Economic Review, 59, 2, 1-16. 